\title{
Notes and descriptions of Neotropical Macrotomini (Coleoptera, Cerambycidae, Prioninae)
}

\author{
Frank T. Hovore ${ }^{1} \&$ Antonio Santos-Silva ${ }^{2}$
}

${ }^{1} 14734$ Sundance Place, Santa Clarita, CA 91387 USA.

${ }^{2}$ Museu de Zoologia, Universidade de São Paulo. Caixa Postal 42494, 04218-970 São Paulo-SP, Brazil.

\begin{abstract}
Resumo. Notas e descrições em Macrotomini neotropicais (Coleoptera, Cerambycidae, Prioninae). Mallodon vermiculatus sp. nov. procedente do Panamá e Nothopleurus santacruzensis sp. nov., da Bolívia, são descritas e ilustradas. Mallodon dasystomus dasystomus $($ Say, 1824) $=$ Mallodon mandibularis Lackerbeck, 1998 syn. nov.

Palavras-Chave. Mallodon; espécies novas; Nothopleurus; Prioninae; sinonímia.
\end{abstract}

Abstract. Mallodon vermiculatus sp. nov. (from Panama) and Nothopleurus santacruzensis sp. nov. (from Bolivia) are described and illustrated. Mallodon dasystomus dasystomus (Say, 1824) = M. mandibularis Lackerbeck, 1998 syn. nov.

KEYwords. Mallodon; new species; Nothopleurus; Prioninae; synonymy.

The New World Macrotomini, Thomson, 1860 mostly are larger species, similar in general appearance, usually brown in dorsal coloration, with well-developed mandibles in both sexes, but particularly in the males. Characters by which some taxa have been distinguished have been viewed or interpreted differently by various workers, and a comprehensive study of individual variation and phenotype distribution is needed to resolve the relationships of some of the more widespread and abundantly collected subspecies and species. This paper proposes two distinctive new species and one new synonym from Central America.

Bibliographical citations on Mallodon dasystomus dasystomus (Say, 1824), relative to the synonymy proposed, are restricted to the original description, MonNÉ's catalog (1995), and citations subsequent to that catalog.

The acronyms used in the text are as follows: AMCM, American Coleoptera Museum, Texas, U.S.A. (= J. E. Wappes collection); EMEC, Essig Museum of Entomology, University of California, Berkeley, California, U.S.A.; FSCA, Florida State Collection of Arthropods, Gainesville, Florida, U.S.A.; FTHC, Frank T. Hovore Collection, Sundance Place, Santa Clarita, U.S.A.; MCNZ, Museu de Ciências Naturais, Fundação Zoobotânica do Rio Grande do Sul, Porto Alegre, Rio Grande do Sul, Brazil; MNRJ, Museu Nacional, Universidade Federal do Rio de Janeiro, Rio de Janeiro, Brazil; MZSP, Museu de Zoologia, Universidade de São Paulo, São Paulo, Brazil; USNM, National Museum of Natural History, Washington D. C., U.S.A.

\section{Mallodon vermiculatus sp. nov.} (Figs. 1 - 3)

Male (Fig. 1). Integument red-brown to castaneous; elytra lighter red-brown, head, mandibles, scape, second and third antennal segments, prothorax and profemora darker. Dorsal surface of the head with deep, coarse punctures scattered on occiput and anastomosing toward the front; front and clypeus with smaller, scattered punctures, each of which gives rise to a long, erect hair. Labrum sub-horizontal, clothed with long, erect hairs, apex acuminate and projecting anteriorly. Postocular region coarsely, deeply punctate, becoming confluent toward the lower eye lobe, with well-marked transverse furrows behind the eye and scattered punctures toward the gula. Genal apex angular with a single, anteriorly projecting, rounded apical tooth. Hypostomal semicircular depression deep, distinctly delimited by elevated lateral margins (Fig. 3), inner surface deeply, coarsely vermiculate.

Mandibles elongate, relatively narrow, distinctly longer than head, arcuate at apex; dorsal carina strongly elevated from base to near apex, terminating abruptly and forming nearly a $90^{\circ}$ angle with the dorsal surface before apical tooth; external surface with scattered, moderately coarse punctures, more concentrated apically; ventral surface deeply, longitudinally excavated, nearly glabrous and impunctate; internal surface clothed along lower one-half with a dense fringe of long erect hairs; inner margin irregularly dentate from base to apex, with a large, triangular tooth at basal one-third and another, slightly smaller, at the apical third, between which is an uneven series of small, sub-triangular teeth, and a single small tooth behind the large tooth at basal third; apices broadly bifid, outer apical tooth long and acute, inner apical tooth narrowly rounded. Antennae extending to near middle of elytra; scape narrow, strongly arcuate, slightly expanded apically, elongate, more than twice as long as antennomere III, longer than III and IV together, attaining the anterior margin of the pronotum; remaining segments simple, subcylindrical, antennomeres III and IV subequal in length, V and VI slightly longer, subequal, successive segments slightly increasing in length.

Prothorax transverse, about twice as wide as long; anterior angles rounded and only slightly projecting anteriorly; 

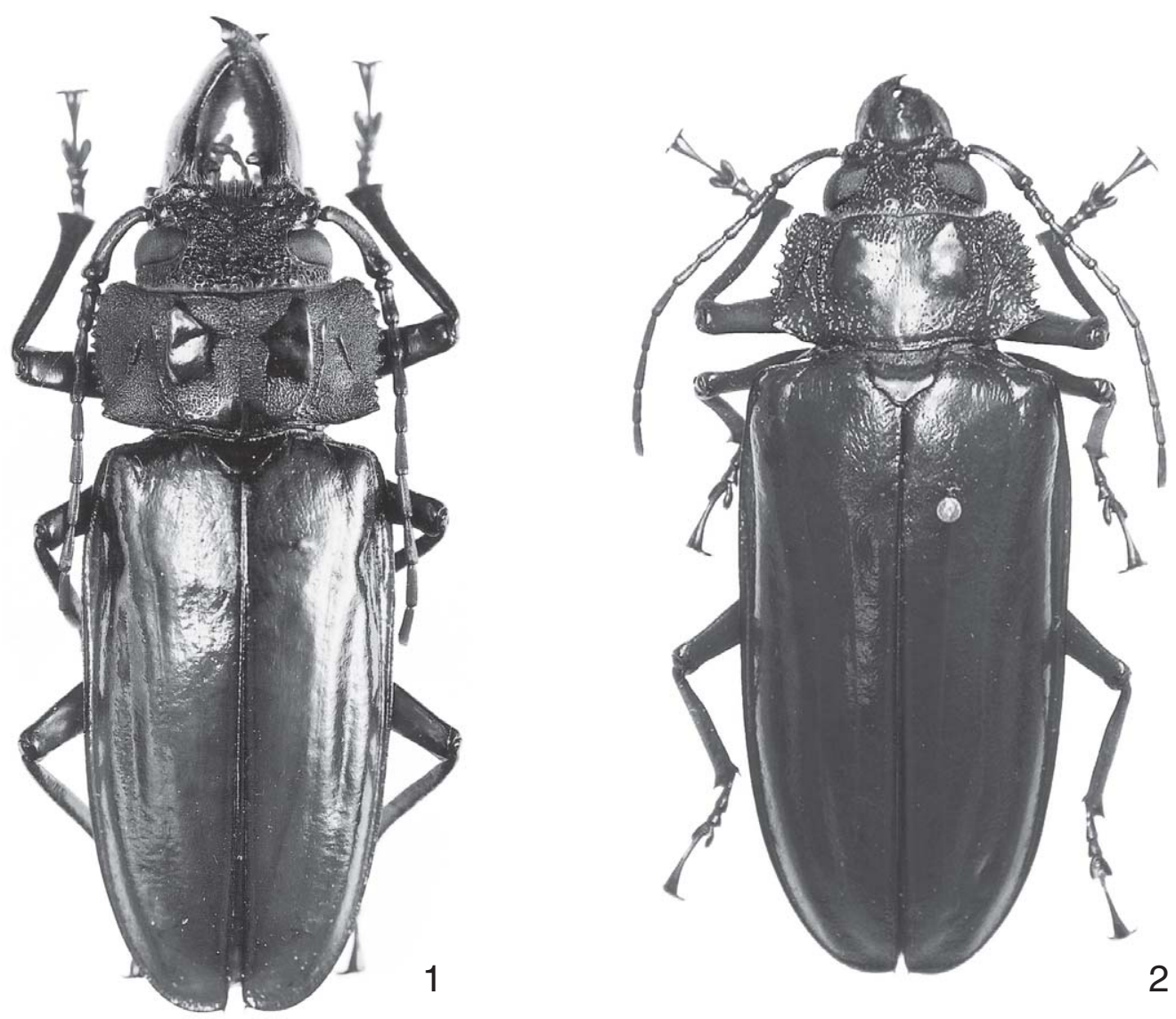

Figs. 1-2. Mallodon vermiculatus sp. nov., dorsal view: 1, holotype male, length 74,3 mm; 2, paratype female, length $64,5 \mathrm{~mm}$.

posterior angles obtuse, dentate; lateral margins sharply, irregularly crenulate; anterior margin slightly concave medially; posterior margin bi-sinuate. Pronotal disk with two separate, elevated, shining central callosities, and two small, elevated, somewhat linear calluses laterally, discal surface around and between callosities closely, moderately-coarsely punctate, becoming confluently punctate laterally. Prosternum and intercoxal process closely, moderately finely punctate; proepisternum with coarser, anastomosing punctures. Mesosternum with punctures similar to those of prosternum, but confluent; disc glabrous medially, clothed laterally with short, fine hairs. Mesepisternum and mesepimeron finely, shallowly punctate, clothed with short, fine hairs. Median portion of metasternum with a triangular-shaped, impunctate and glabrous area; finely, closely punctate and pubescent laterally and near meta-coxae. Metepisternum very finely granulate-punctate, densely, finely pubescent. Scutellum broad, rounded, glabrous and impunctate. Elytra nearly impunctate, slightly coriaceous basally; lateral margins narrowly explanate, rounded to suture, sutural angle with a short spine. Urosternites I-IV glabrous, minutely granulatepunctate laterally; fifth visible urosternite rounded apically, apex thinly fringed with long erect hairs.

Female (Fig. 2). Similar in size and coloration to male, differing by the following characters: form slightly more robust; antennae shorter, reaching basal one-third of elytra; mandibles shorter than head, stout, dorsal carina less strongly elevated, evenly rounded at terminus before apical tooth, apex slightly more broadly bifid, inner margin irregularly dentate from base to apex, larger teeth less pronounced, outer surface densely, moderately-coarsely punctate. Prothorax with anterior angle rounded, moderately projecting anteriorly, posterior angle strongly, acutely dentate, lateral margins deeply, coarsely crenulate-dentate; pronotal disk with entire central area smooth, elevated, nearly impunctate, lacking separated calluses, lateral portions of disk with three irregular, elevated longitudinal callosities, anterior and posterior margins confluently punctate, remainder of disk coarsely vermiculate. Prosternum glabrous and nearly impunctate, margins feebly rugulose, proepisternum feebly vermiculate. Mesosternum glabrous medially, minutely granulate-punctate and finely pubescent laterally. Scutellum broadly angulated, apex obtusely rounded. Urosternites minutely granulate-punctate laterally, fifth urosternite with a few fine, short hairs apically.

Dimensions in mm (male / female). Total length (including mandibles), 58,5-74,3 / 49,0-64,5; prothorax length, 9,0-10,3 / 7,3-9,5; prothorax width, 16,5-21,5 / 10,5-18,5; elytral length, 31,5-41,8 /34,5-45,0; humeral width, 16,5-20,0 / 15,0-21,0. 


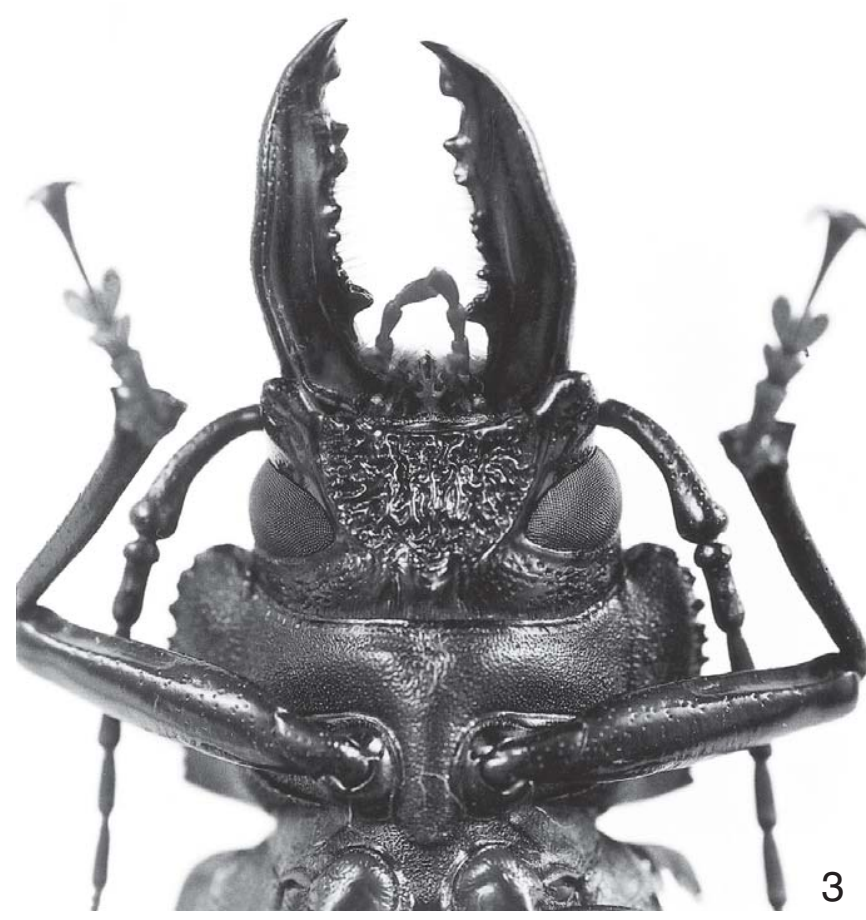

Fig. 3. Mallodon vermiculatus sp. nov., holotype male, ventral view (anterior one-third)

Type material. Holotype male from PANAMA, Panamá: Rodovia El Llano-Carti (km 8-13), 21-24.V.1996, J. E. Wappes, Huether \& Morris col. (USNM). Paratypes. PANAMA, Panamá: Cerro Azul (1,800'), 1 male and 1 female, 14-22.V.1987; 1 female, 3.VI.1986, E. F. Giesbert coll. (FSCA); Cerro Azul/Jéfe (= same locality as E. F. Giesbert specimens, taken near the gate for the "Altos de Azul" residential development), 1 female, 11-12.V.1994, F. T. Hovore coll. (FTHC).

Comments. Mallodon vermiculatus sp. nov. may be distinguished from all other species in the genus by the combination of elongate male mandibles with the inner margin irregularly dentate, and the denticulation extending the entire length of the mandible, the triangular tooth at the basal third of the mandible (similar to that of some Stenodontes AudinetServille, 1832), slender, elongate, strongly arcuate antennal scape, more than twice the length of antennomere III, and longer than antennomeres III and IV together, and deeply impressed, coarsely vermiculate hypostomal area. From $M$. molarius Bates, 1879 , with which it is generally sympatric in central Panamá (although found at a slightly higher elevation) it further differs by the lighter coloration, less-depressed body form, only the lower one-half of the inner margins of mandibles densely punctate-pubescent (entirely so in M. molarius), very differently shaped prothorax in both sexes (anterior angles strongly produced anteriorly, posterior angles broadly rounded in M. molarius), and relatively longer, slender femora. Mallodon linsleyi Fragoso \& Monné,1995, from Peru and
Brazil, has more massive, rounded male mandibles, minutely punctate hypostomal area, and laterally-projecting genae. Males of Mallodon hermaphroditus Thomson, 1867, have an elongate scape similar to M. vermiculatus, but are easily distinguished by the central area of the pronotal disk smooth and lightly punctate, without distinct calluses or ridges, and the lateral margins denticulate (see FraGoso \& MonNÉ 1995).

Etymology. Named for the coarsely vermiculate sculpturation of the hypostomal area in both sexes and lateral portions of the female pronotal disk.

\section{Mallodon dasystomus dasystomus (Say, 1824)}

Prionus dasystomus Say, 1824: 326.

Stenodontes (Orthomallodon) dasytomus dasytomus [sic]; Noguera \& Chemsak, 1996: 396 (distr.).

Stenodontes dasytomus [sic]; Browne \& Peck, 1996: 2158, 2160 (distr.).

Stenodontes dasytomus dasytomus [sic]; Linsley \& Chemsak, 1997: 434 (hosts).

Mallodon dasystomus; Chemsak, 1996: 78, pl. IV, figs. 11-12 (syn.). Mallodon dasystomus dasystomus; Monné, 1995: 9 (cat.).

Mallodon dasytomus dasytomus [sic]; Yanega, 1996: 26, pl. 1, figs. 6a-6b.

Mallodon mandibularis Lackerbeck 1998: 517 [non Gemminger, 1872]. Syn. nov.

The characters of mandibular shape, dorsal punctation and elytral configuration by which this putative species was characterized are entirely embraced within separate series of typical M. dasystomus from southern Texas, southern Florida, Mexico, and Costa Rica (the type locality for M. mandibularis Lackerbeck). The Lackerbeck name was preoccupied by Mallodon mandibulare Gemminger, 1872 (= Nothopleurus lobigenus Bates, 1884).

\section{Nothopleurus santacruzensis sp. nov.}

(Figs. 4-8)

Male (Fig. 4). Integument dark brown. Dorsal surface of head depressed; coarsely, deeply, confluently punctate, punctures smaller toward frontal suture; front and clypeus shallowly punctate, with scattered, long erect hairs. Labrum subperpendicular to clypeal margin, clothed with long, moderately dense hairs; triangular projection rounded at apex. Post-ocular region coarsely, confluently punctate around lower eye lobe, granulated medially, with scattered punctures extending toward gula. Genal apex projecting laterally, rounded. Hypostomal area (Fig. 6) depressed, coarsely vermiculate, punctate antero-medially. Mandibles approximately 1.2 times longer than head, greatly enlarged beyond base, narrowed at apical two-thirds and then onward to apex; dorsal carina elevated from base to near apex, terminating in an approximately $45^{\circ}$ angle to the dorsal surface of apical tooth; external surface punctate, internal surface concave, densely clothed with long, erect hairs; inner margin with three consecutive teeth at apical one-third, sinuated at basal two-thirds; ventral surface slightly excavated longitudinally, with scattered punctures at base, 

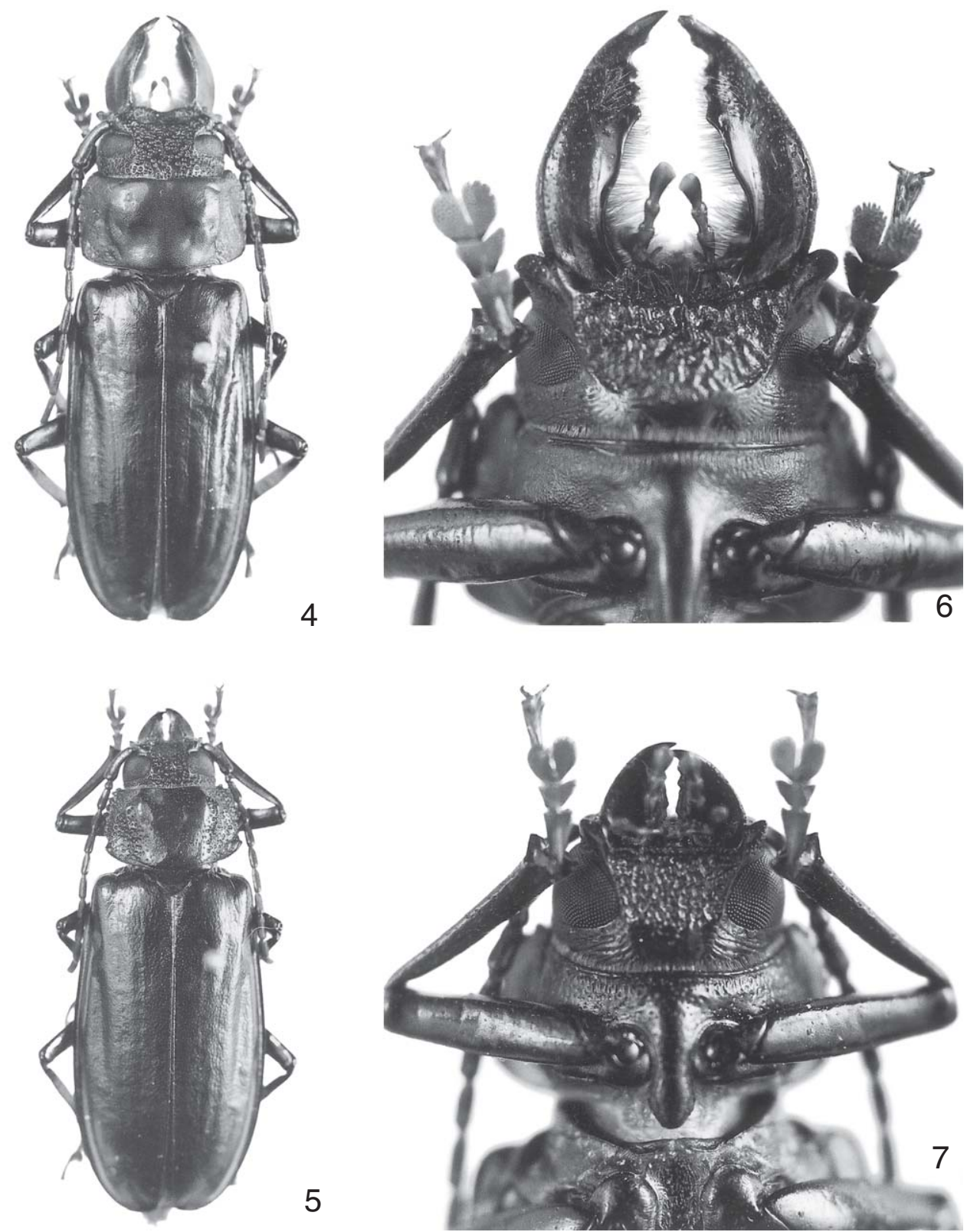

Figs. 4-7. Nothopleurus santacruzensis sp. nov.: 4, 6, hototype male, length $42,8 \mathrm{~mm} ; \mathbf{5}, \mathbf{7}$, paratype female, length $31,1 \mathrm{~mm}$.

becoming abundant at apical one-third; apex narrow, outer apical tooth acute, inner apical tooth obtuse. Antennae surpassing the middle of elytra; scape curved, strongly enlarged toward apex, surpassing the posterior margin of the eye.

Prothorax transverse; anterior angles rounded, feebly projected; posterior angles obtuse or rounded; lateral margin feebly crenulate; anterior margin feebly concave; posterior margin sinuate. Shining callosities of pronotum feeble, surrounding area of disk finely, closely punctate, punctures anastomosing towards lateral margin. Prosternum and intercoxal process closely punctured; proepisternum with punctures more scattered than on prosternum. Mesosternum closely, finely, confluently punctate, laterally clothed with fine, dense pubescence. Mesepisternum and mesepimeron finely granulate-punctate, clothed with short, moderately dense pubescence. Metasternum with an impunctate, triangular, median area, remainder finely, densely punctate and pubescent. Metepisternum finely granulate-punctate, with fine pubescence more conspicuous than that of metasternum. Elytra nearly impunctate, sometimes feebly ridged longitudinally; sutural apex with a short spine. Urosternite I-IV finely granulate laterally; apex of fifth urosternite truncate, apically fringed with long hairs.

Female (Fig. 5). Similar to male, differing as follows: antennae attaining basal one-third of elytra; scape not 

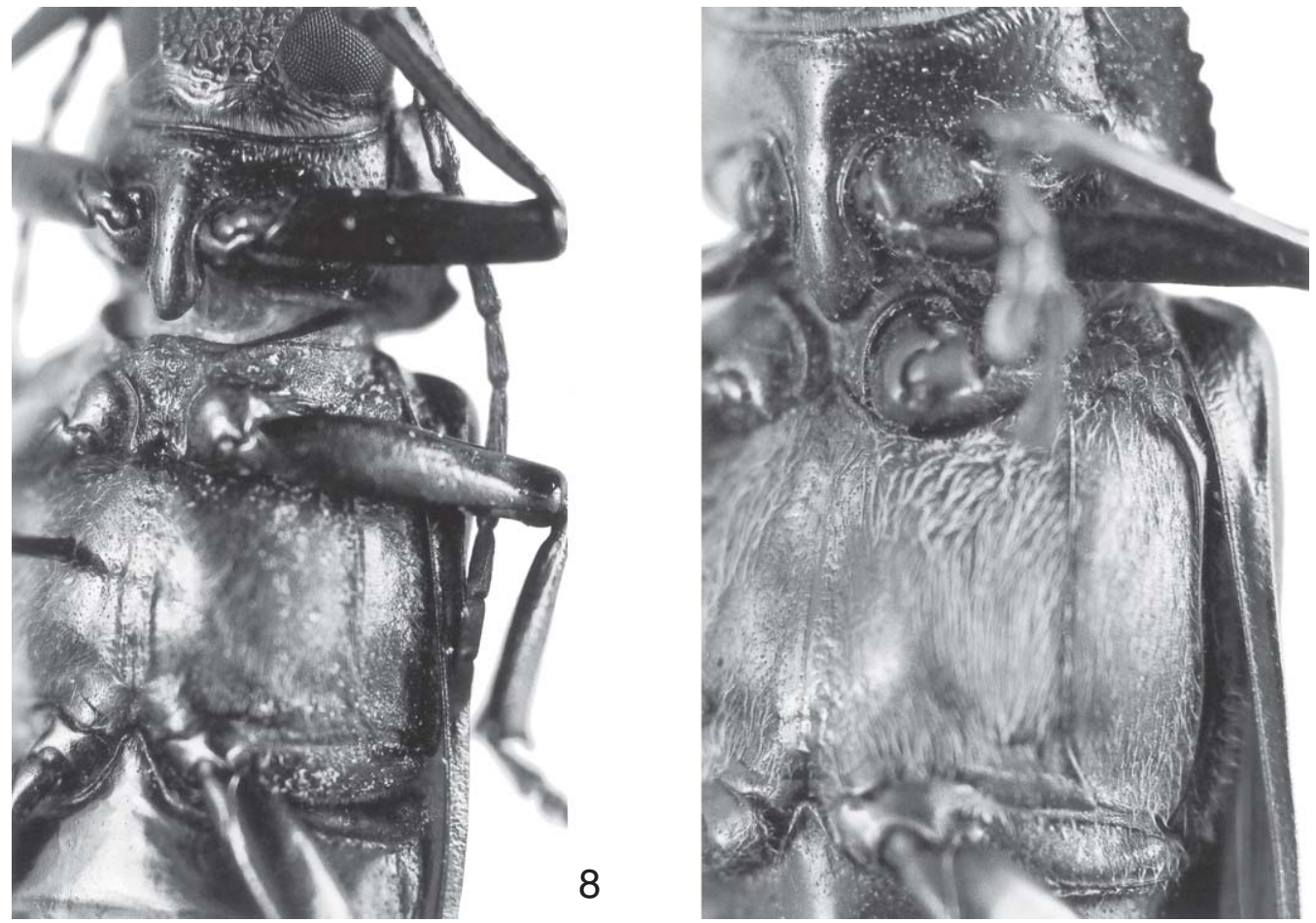

Figs. 8-9. Metepisternum: 8, Nothopleurus santacruzensis sp. nov., paratype female; 9, Mallodon dasystomus baiulus Erichson, 1847, female.

surpassing posterior margin of eye; hypostomal area (Fig. 7) with coarse, anastomosing punctures; pronotum without discal callosities, disk finely, irregularly punctate, punctures becoming coarser laterally; prosternum with fine, scattered punctures; apex of fifth urosternite convex.

Dimensions in mm (male / female). Total length (include mandibles), 20,2-42,8 / 28,9-35,5; prothorax: length, 3,4-6,9 / 4,6-6,2; Larger width, 6,1-12,0 / 8,0-10,1; elytral length, 13,624,6 / 18,9-25,2; umeral width, 6,0-11,5 / 8,5-11,1.

Type material. Holotype male, BOLIVIA, Santa Cruz: 4-6 km SSE Buena Vista (Hotel Fauna \& Flora), 22-31.X.2002, J. E. Wappes \& Morris col. (USNM). Paratypes, same locality of the holotype: 1 male, 31.X.1999, C. Porter \& L. Stange col. (FSCA); 2 males, 17-19.IX.2000, Wappes \& Morris col. (FSCA); 1 female, 27-29.IX.2000, Wappes \& Morris col. (FSCA); 1 male, 14-16.X.2000, Wappes \& Morris col. (FSCA); 1 male, 23-26.X.2000, M. C. Thomas col. (FSCA); 4 males, 23-26.X.2000, Wappes \& Morris col. (EMEC); 6 males, 2 females, 27-29.X.2000, Wappes \& Morris col. (EMEC); 9 males, 2 females, 515.XI.2001, M. C. Thomas \& B. K. Dozier col. (FSCA); 1 male, 1 female, M. C. Thomas \& B. K. Dozier col. (MZSP); 2 males, 2 females, 15-22.XI.2001, B. K. Dozier col. (FSCA); 1 female, 15-22.XI.2001, M. C. Thomas \& B. K. Dozier col. (FSCA); 2 males, 3 females, 2231.X.2002, Wappes \& Morris col. (FSCA); 1 male, 1 female, 18.XI.2002, J. E. Wappes col. (MZSP); 1 female, 1-8.XI.2002, J. E. Wappes col. (FSCA); 1 female, 1-8.XI.2002, J. E. Wappes col. (FSCA); 1 male, 1-8.XI.2002, J. E. Wappes col. (MNRJ); 1 female, 1-8.XI.2002, J. E. Wappes col. (MCNZ).

Comments. Nothopleurus santacruzensis sp. nov. resembles $N$. subcancellatus (Thomson, 1867), but males differ from that species as follows: mandibles longer and narrower at apical third; dorsal carina of the mandibles sub-linear; scape clearly surpassing the posterior margin of the eye; hypostomal area not tumid, vermiculate; anterior prothoracic angles short and feebly projecting anteriorly. In N. subcancellatus the mandibles are shorter and slightly narrowed at apical third; the dorsal carina of the mandibles is convex at middle; the scape usually does not surpass the margin of the eye; the hypostomal area is tumid, not vermiculated, or very slightly vermiculate antero-medially; the anterior angles of the prothorax are large and strongly projecting anteriorly. Females differ as follows: scape reaching the margin of the eye; anterior prothoracic angles narrowed and feebly or not at all projecting anteriorly; in female $N$. subcancellatus the scape does not reach the margin of the eye, and the anterior prothoracic angles are relatively large and strongly projecting.

In two paratype females of $N$. santacruzensis $\mathbf{s p . ~ n o v . ~ t h e ~}$ genal apex is slightly bifid, a character shared with some female specimens of N. subcancellatus. Mallodon dasystomus baiulus Erichson, 1847 females are very similar in general appearance, but can easily be distinguished by the form of the metepisternum: narrow and frequently concave at inner margin in $N$. santacruzensis sp. nov. (Fig. 8); wide and convex at inner margin in Mallodon (Fig. 9).

Etimology. Named for the region of the type locality, Santa Cruz, Bolivia.

Acknowledgements. To Dr. J. E. Wappes (AMCM) and Dr. Michael Thomas (FSCA) for the loan of specimens. 


\section{REFERENCES}

Browne, J. \& S. B. Рeck. 1996. The Long-horned beetles of south Florida (Cerambycidae: Coleoptera): biogeography and relationships with the Bahama Islands and Cuba. Canadian Journal of Zoology 74(12): 2154-2169.

Chemsak, J. A. 1996. Illustrated Revision of the Cerambycidae of North America. Parandrinae, Spondylidinae, Aseminae, Prioninae. Burbank, Wolfsgarden Books, 1: x + 1-150.

Fragoso, S. A. \& M. A. Monné. 1995. Notes on Macrotomini (Coleoptera, Cerambycidae, Prioninae). Revista Brasileira de Biologia 55(2): 215-225.

LACKeRBeCK, K. 1998. Neue und wenig bekannte Prioninae (Coleoptera, Cerambycidae). Entomofauna Zeitschrift für Entomologie 19(32): 517-524.

Linsley, E. G. \& J. A. Chemsak. 1997. The Cerambycidae of North America, Part VIII: Bibliography, Index, and Host Plant Index. University of California Publications in Entomology 117: ix $+1-534$.
Monné, M. A. 1995. Catalogue of the Cerambycidae (Coleoptera) of the Western Hemisphere. Part XXII, Subfamily Prioninae. São Paulo, Sociedade Brasileira de Entomologia, 115 p.

Noguera, F. A. \& J. A. Chemsak. 1996. Cerambycidae (Coleoptera), p. 381-409. In: Llorente Bousquets \& Morrone (Eds.). Biodiversidad, Taxonomía y Biogeografía de Artrópodos de México: Hacia una Síntesis de su conocimiento. Mexico, Universidad Nacional Autonoma de México.

SAY, T. 1824. Descriptions of coleopterous insects collected in the late expedition to the Rocky Mountains, performed by order of Mr. Calhoun, Secretary of War, under the command of Major Long. Journal of the Academy of Natural Sciences of Philadelphia 3(2): 298-331.

YANEGA, D. 1996. Field Guide to Northeastern Longhorned Beetles (Coleoptera: Cerambycidae). Illinois Natural History Survey, Manual 6: 1-174. 